\title{
Conceptualizing and Measuring Global Justice: Theories, Concepts, Principles and Indicators
}

\author{
Sujian Guo ${ }^{1}$ - Xi Lin ${ }^{1}$ - Jean-Marc Coicaud ${ }^{1}$ - Su Gu ${ }^{1}$. Yanfeng Gu ${ }^{1}$. \\ Qingping Liu ${ }^{1} \cdot$ Xuan Qin $^{1} \cdot$ Guodong Sun ${ }^{1} \cdot$ Zhongyuan Wang $^{1}$. \\ Chunman Zhang ${ }^{1}$
}

Received: 18 June 2019 / Accepted: 13 July 2019 / Published online: 23 July 2019

(c) The Author(s) 2019, corrected publication 2020

\begin{abstract}
s
The paper focuses on the conceptualization and measurement of global justice and discusses theories, concepts, evaluative principles, and methodologies related to the study of global justice. In this paper, we seek to clarify how to conceptualize global justice, how conceptual indicators can be selected and justified by theories, and how those indicators can be conceptually consistent with the concept of global justice. Global justice is a broad concept that is composed of multi-level and multidimensional aspects belonging to both normative and empirical realities. A coherent and integrated theoretical framework that covers the normative basis and various empirical dimensions is therefore much needed in order to address some of the basic and important questions under study. The paper seeks to synthesize the multiple theories and conceptions of global justice that exist in the academic discourse and literature into three main theoretical approaches to global justice-rights based, good based, and virtue based. These three approaches are a good sample of and reflect well the strengths of the different theoretical, intellectual and cultural traditions at play in the study of global justice. From this perspective, the synthesis of the three approaches is meant to provide us with a coherent theoretical framework that serves as the normative basis and justifies the selection of indicators for measurement.
\end{abstract}

Keywords Global justice · Rights based · Goods based · Virtue based · CBDR-RC · CDDR

This is a group project of Fudan IAS. All members of the group named as authors contributed equally to the study and ranked alphabetically.

$\mathrm{Xi}$ Lin

xilin@fudan.edu.cn

1 Fudan Institute for Advanced Study in Social Sciences, Fudan University, Shanghai, China 
The paper focuses on the conceptualization and measurement of global justice and discusses theories, concepts, evaluative principles, and methodologies related to the study of global justice.

In this paper, we seek to clarify how to conceptualize global justice, how conceptual indicators can be selected and justified by theories, and how those indicators can be conceptually consistent with the concept of global justice.

We recognize that in contemporary debates there exist some major theoretical approaches concerning the conceptualization of the ideas of global justice and that these ideas are understood, used and discussed in theoretical, institutional, and policy contexts. Thus, global justice is a broad concept that is composed of multi-level and multidimensional aspects belonging to both normative and empirical realities. A coherent and integrated theoretical framework that covers the normative basis and various empirical dimensions is therefore much needed in order to address some of the basic and important questions under study.

The paper seeks to synthesize the multiple theories and conceptions of global justice that exist in the academic discourse and literature into three main theoretical approaches to global justice — rights based, good based, and virtue based. These three approaches are a good sample of and reflect well the strengths of the different theoretical, intellectual and cultural traditions at play in the study of global justice. They also capture the essence, characteristics, and major dimensions of justice at the global level. From this perspective, the synthesis of the three approaches is meant to provide us with a coherent theoretical framework that serves as the normative basis and justifies the selection of indicators for measurement.

We also recognize the difficulties and challenges associated with the measurement of global justice. We therefore develop two evaluative principles for measurement to serve as guidelines in the selection and operationalization of conceptual indicators-seeking as much to connect with the theoretical approaches as to compile the indicators. These two principles are not only consistent with global justice theories, but they justify the selection of the issue areas covered in this research project. Finally, we will address questions of methodology to be employed in this research in terms of measurement, data availability and data limitations, which would lay down the ground work for further empirical research, data collection, and data analysis.

\section{Rights-Based Conceptualization of Global Justice}

\subsection{The Conception of Justice}

Our conception of justice is mainly based on social justice. As Rawls points out: "For us the primary subject is the basic structure of society, or more exactly, the way in which the major social institutions distribute fundamental rights and duties and determine the division of advantages from social cooperation." (Rawls 1999, p. 6) The study of justice has been concerned with what we owe one another, and what obligations we might have to treat each other fairly in a range of domains, including over distributive and recognitional matters. Classical and contemporary political 
philosophers have focused their theorizing on justice almost exclusively within the state, but the last 20 years or so have seen a marked extension to the global sphere, with a huge expansion in the array of topics covered.

The quest for justice happens in a social context, and its objective is to ensure that the interests of actors are made compatible. This amounts to at the same time limiting and socializing these interests by embedding them into a logic and dynamic of rights and duties of actors toward one another. The rights of actors are secured to the extent that they acknowledge having duties and responsibilities toward others. The recognition by an actor of the rights of other actors secures some sense of order, creating the preconditions in which justice is possible. This is to say, justice enables the possibility of relations of reciprocity and cooperation among actors.

The most important rights and associated duties and responsibilities at the core of a theory of justice tend to have two main features. 1. They concern the rights without which people cannot sustain themselves, and the absence of which also places the stability of the polity or community at risk. 2. They concern the core values on which the identity of a society and its members is structured and organized. From this perspective, a significant aspect of a theory of justice amounts to theorizing and evaluating how these two features come together in a society.

On these most important rights, justice is in principle uncompromising. Actors have equal rights, such as the right of equal respect and treatment, as John Rawls expounds on the two principles of justice: "First: each person is to have an equal right to the most extensive scheme of equal basic liberties compatible with a similar scheme of liberties for others. Second: social and economic inequalities are to be arranged so that they are both (a) reasonably expected to be to everyone's advantage, and (b) attached to positions and offices open to all" (Rawls 1999, p. 53). These principles primarily apply to basic structure of society. They are to govern the assignment of rights and duties and to regulate the distribution of social and economic advantages. These principles are to be arranged in a serial order with the first principle prior to the second. Thus, what makes just arrangements so important is that the rights they protect are uncompromising, which is in the first order. ${ }^{1}$ And, according to Rawls, one of the important principles of equality for distributive justice is equality of opportunity, which means that everyone is equal in her chances of receiving education, getting a position in public office, etc., irrespective of her race, nationality, family background, and so on.

In addition to the most important or core (or primary) rights and duties and responsibilities, there are also rights that are far from peripheral. Incidentally, as societies develop and acquire more resources, it seems that more and more rights have been recognized as primary rights. ${ }^{2}$ To some extent this phenomenon suggests that justice is not an absolute, fixed and unyielding concept but rather a concept that is somewhat fluid and that grows organically as societies grow richer in access to resources and start to recognize rights that were hitherto marginal as

\footnotetext{
1 We want to thank Charles Beitz for commenting on what makes these rights primary for justice.

2 We want to thank Nannerl Keohane for suggesting to us that more rights have been recognized as primary rights, but that doesn't mean they become equivalent in importance to survival-linked rights.
} 
basic rights, for example, the right to clean water or clean air, the right to privacy, etc.

The principal responsibility of political institutions, such as the state, is to ensure the respect of what actors see as their rights and duties, especially those at the core of their sense of justice. The possibility and enjoyment of rights (and duties) is a key aspect of the function and responsibility of political institutions, especially if they aspire to be viewed as legitimate. One of the ways in which political institutions can achieve such outcomes is to produce and nurture public goods in the fields of security, economics, health, education, etc.

The protection of the rights of every person is a duty for any political institution. Human rights belong to all individuals regardless of their citizenship, nationality, culture and other forms of associative membership. Article 2 of The Universal Declaration of Human Rights reiterates this universality and individuality of human rights as follows:

"Everyone is entitled to all the rights and freedoms set forth in this Declaration, without distinction of any kind, such as race, color, sex, language, religion, political or other opinion, national or social origin, property, birth or other status. Furthermore, no distinction shall be made on the basis of the political, jurisdictional or international status of the country or territory to which a person belongs, whether it be independent, trust, non-self-governing or under any other limitation of sovereignty".

As a universal ideal, the protection and securing of the human rights of individuals is not solely the purview of their respective states. States may well be the primary moral agents tasked with securing and protecting the human rights of their own citizens, but human rights are ultimately a matter of international concern. When a state fails to live up to its human rights duties, the international community has the responsibility to respond appropriately. The universality of human rights, therefore, has important practical implications (Tan 2017, p. 60).

In recent years, in addition to rights or the institutionalist approach to justice, some other approaches have been developed, including the capability approach put forward by Amartya Sen and others. According to this approach, individual advantage is judged by a person's capability to do things she or he has reason to value. Its focus is on the freedom that a person actually has to do this or be that. Obviously, the things we value most are particularly important for us to be able to achieve. The concept of capability is thus linked closely with the opportunity aspect of freedom, seen in terms of "comprehensive" opportunities. Consequently, the capability approach aims at equality of opportunity, but focuses on information in judging and comparing overall individual advantages. A number of distinguished contributions have been made by Martha Nussbaum and others on matters of social assessment and policy through powerful use of the capability approach (Sen 2009, pp. 231-232; Nussbaum 2006). The realization of justice depends not only on defending individual rights to freedom, but also on developing a person's capability or social functions to realize her freedom, such as satisfaction of basic needs, conditions that lead to a decent life, better education, etc. 


\subsection{Global Justice}

Global justice builds on key intuitions and insights developed in the framework of justice as it has been traditionally explored in the context of local and national communities. It is the pursuit of justice at the global level, i.e., at the level of the whole of humanity. As such, global justice entails at least four related defining features:

1. It makes human beings, whoever they are and wherever they are, the primary right holders.

2. It addresses issues that in nature and scope must be to a significant extent taken up at the global level (like climate change and the global political economy).

3. Addressing features 1 and 2 requires some sort of global community conscience, made of shared global values and prudential considerations (a mix of projection of values by powerful countries, negotiation in the context of international agreements and the need to cooperate with one another). ${ }^{3}$

4. Addressing features 1,2, and 3 calls for conceiving and establishing public goods at the global level and making them complementary with the pursuit of public goods at the national and regional levels.

These four features are by and large the benchmarks of global justice. Since there are some differences between justice within a country and justice between nations, the universal standards that exist in such issues as human rights, democracy, equality, freedom, etc., serve as a common denominator for people between nations to deal with each other.

In its most comprehensive dimension, a theory of global justice entails the following four related dimensions: (1) A normative dimension: Which criteria and values should be used for evaluating and judging what is just from a global standpoint, and the nature of the rights? (2) A methodological and procedural dimension: Which procedures and mechanisms should be mobilized to identify and implement the substance of rights? (3) An institutional dimension: Which institutions and laws are best suited to an agenda of global justice? (4) A policy dimension: Which policies should be put in place to nurture access to and respect of rights at the global level?

The concept of global justice, just as the concept of justice in the national context, recognizes different kinds of rights and their statuses in the evaluation of justice. As with justice in general, primary rights at the global level concern equal treatment of all peoples, physical, economic and health security, access to education, etc. The pursuit of the respect of these rights takes place especially in the context of the development of public goods, as articulated between the national and the global levels. For instance, given the growing economic interdependence of countries (globalization), the pursuit of economic and environmental justice calls for establishing

\footnotetext{
${ }_{3}^{3}$ Although in today's world, a global community conscience is hard to define, and there are many differing, even clashing viewpoints on values, from a normative perspective, shared values and consensus are still necessary for global justice. We want to thank Nannerl Keohane and Robert Keohane for their comments on this issue.
} 
a complementarity of rights and duties and public goods at the national and global levels. Those in international human rights circles talk about 'first-', 'second-' and 'third-generation' rights (see Alston 1987, p. 307). First-generation rights are the traditional liberties and privileges of citizenship: religious toleration, freedom from arbitrary arrest, free speech, the right to vote, and so on. Second-generation rights are socio-economic claims: the right to education, housing, healthcare, employment and an adequate standard of living. Though these are thought to be more radical claims requiring a more interventionist state, they remain essentially individualistic in their content, inasmuch as it is the material welfare of each man, woman and child that is intended to be secured by these provisions. Third-generation rights, in contrast, have to do with communities or whole peoples, rather than individual persons. They include minority language rights, national rights to self-determination and the right to such diffuse goods as peace, environmental integrity and economic development. But when reordering is needed, respect for human rights takes priority over respect for peoples, as a government should take the respect of the rights of its individual citizens most seriously. ${ }^{4}$

Global justice concerns principles dealing with international relations. Rawls' Law of Peoples was a significant work that stimulated thinking about global justice. Several questions soon became prominent in the discussions related to global justice, including: What principles should guide international action? What responsibilities do we have to the global poor? Should global inequality be morally troubling? Are there types of non-liberal polities that should be tolerated? What kind of foreign policy is consistent with liberal values? Is a "realistic utopia" possible in the global domain?

As Rawls points out, his principles of justice among free and democratic peoples include: peoples are free and independent, and their freedom and independence are to be respected by other peoples; peoples are equal and are parties to the agreements that bind them; and peoples are to observe a duty of non-intervention. ${ }^{5}$ Rawls stresses that free and independent well-ordered peoples are ready to recognize certain basic principles of political justice as governing their conduct, and these principles constitute the basic charter of the Law of Peoples (Rawls 1999, pp. 36-37).

Equal respect and treatment of all peoples should be universal, namely not only for those in liberal democratic and decent societies, but also for those of outlaw states or those in unfavorable conditions. A principle of justice such as that of nonintervention may have to be qualified in the general case of outlaw states and grave violations of human rights, but the principle of equal respect and treatment still applies to all peoples. For those outlaw states, when humanitarian disasters happen,

\footnotetext{
${ }^{4}$ We want to thank Charles Beitz for commenting on the relationship between the two kinds of respect.

5 Here peoples are somehow different from states or nations, as Rawls points out: "what distinguishes peoples from states - and this is crucial-is that just peoples are fully prepared to grant the very same proper respect and recognition to other peoples as equals. Their equality doesn't mean, however, that inequalities of certain kinds are not agreed to in various cooperative institutions among peoples, such as the United Nations, ideally conceived. This recognition of inequalities, rather, parallels citizens' accepting functional social and economic inequalities in their liberal society" (Rawls 1999, p. 35). We want to thank Nannerl Keohane for noticing the difference.
} 
it is possible to envision sanction or intervention, as equal treatment of all peoples is still requisite. From the perspective of international relations, a people is like a person: It has its own personality, and equal rights and respect of persons can be extended to the global context. As peoples enjoy equality of rights, they should not be prejudiced or discriminated against for reasons having to do with their geographical size, population, religion, race, and cultural tradition.

While most moral and political solidarity and global responsibility must be founded or based upon primary rights, global justice must also be evaluated on the basis of how rights that are secondary but are nonetheless significant for human life are respected. This is particularly important since global justice seeks to identify and respect the most important, and as such universal, rights of human beings in the midst of cultural pluralism.

The state or the nation-state can be a key instrument of global justice in creating and maintaining respect for the rights of human beings. The legitimacy of a nationstate regime and even the nation-state itself and its rights will be evaluated on the basis of its contribution to the rights of human beings and public goods both at a national and global level. This is to say that the pursuit of the national interest at the exclusion of rights and public goods beyond borders is at odds with the normative, policy, institutional, and political agenda of global justice. In a global context, the national interest is not exclusively self-centered. It is also geared toward global solidarity and responsibility, and not simply in a marginal fashion. A hierarchy may exist in what a state owes to its people and what it owes to strangers, but this hierarchy is meant to be inclusive (to make room for and look after the rights of strangers, since they are human beings) and not exclusionary.

Supporters of global justice seek to determine, in the service of the rights of individuals, the right balance between just universalism and just particularism and pluralism. They try to adjudicate how the equality and hierarchy (all people should have equal rights of some type but a hierarchy exists between certain kinds of rights) of individual rights should be negotiated, conceptualized and implemented in the midst of the dilemmas that relations between universalism, particularism, and pluralism can create.

Natural resources often figure prominently in several topics of global justice. Some relevant questions include: Are national communities entitled to the resources they find on their territories? Should principles of global justice apply to our arrangements for justly distributing natural resources? As an early proponent of a resource distribution principle, Charles Beitz argues that natural resources should be allocated such that each society is able to provide adequately for its population (Beitz 1975).

\subsection{Conceptualization of Global Justice}

A key problematic for the conceptualization of global justice is: How is it possible to reconcile a cosmopolitan and universalist agenda (primacy of the rights of individuals, especially when it comes to basic security and economic rights) with the 
particularistic logic of nation-states and pluralism of cultures, and the challenges that this can create from both theoretical and practical standpoints?

The eight sets of considerations below could serve as guidelines for the conceptualization of global justice:

1. The rights of human beings have primacy.

2. The rights of states are based on the extent to which they serve the rights of human beings, domestically and internationally, and contribute to the establishment of public goods, nationally and globally, themselves at the service of the rights of human beings. Everyone is entitled to all the rights and freedoms, without distinction of any kind, such as race, color, sex, language, religion, political or other opinion, national or social origin, property, birth or other status. And no distinction shall be made on the basis of the political, jurisdictional or international status of the country or territory to which a person belongs, whether it be independent, trust territory, non-self-governing territory, or under any other limitation of sovereignty.

3. In a justice context, the rights of states are not absolute, or an end in themselves. They are based upon the rights of human beings. As such, nation-states have a key role to play in global justice, both at the domestic and global levels. The fact that the rights of states are based upon their contribution to the rights of human beings and public goods makes them open to criticism if they do not take the requirement of solidarity and responsibility seriously. ${ }^{6}$

4. From the perspective of global justice, the legitimacy of a nation-state will be evaluated on the basis of its contribution to the rights of human beings and public goods nationally but also on the basis of its contribution to these rights at the global level. This is to say that the pursuit of the national interest at the exclusion of rights and public goods beyond borders is at odds with a global justice normative, policy, institutional and political agenda. In a global context, the national interest has to factor in global solidarity and responsibility.

5. Equal respect and treatment of all peoples should be universal. From the perspective of international relations, a people is like a person; It has its own personality, and equal rights and respect of persons can be extended to the global context. As peoples enjoy equality of rights, they should not be prejudiced or discriminated against for reasons having to do with their geographical size, population, religion, race, or cultural tradition.

6. The first priority of global solidarity and responsibility on the part of states, international organizations and other actors (such as non-governmental organizations, the private sector, or individual actors) is to ensure that those rights viewed as basic, as primary rights, are not overlooked nationally and globally. This can entail socio-economic rights, security rights, etc. It is upon these primary rights that the bulk of solidarity and responsibility must be conceived and exercised, and that a sense of global justice must be first and foremost evaluated. But the

\footnotetext{
${ }^{6}$ We want to thank Darrel Moellendorf for commenting on this circumscribed account of the rights of states.
} 
sense of global justice must also be evaluated on the basis of how the rights that are secondary but nonetheless important for human life are respected. In addition, cosmopolitan engagement in the service of global justice should not necessarily lead to a homogenization of ways of life and thinking, or even of modalities of development. Universality of rights does not mean uniformity of rights and ways of life.

7. The key is to identify the nature of primary rights, on which there can be no compromise, and the nature of secondary rights, on which there can be some compromise, and then assess the extent to which they are respected (threshold of realization and implementation). Competition and hierarchy of rights in the context of global justice, and the tensions, dilemmas and trade-offs that come with them, must always be managed in favor of primary rights.

8. The identification and negotiation of these rights (primary and secondary) must be agreed upon by people, and not simply by their government or global institutions, so that people have a say, agency and participation in how they live. This is a key aspect of global justice, as of any level of justice.

\section{Goods-Based Conceptualization of Global Justice}

Justice in the distribution of goods is one of the main topics in the domain of global justice. It deals with the question of the global duty under which we are obliged to ensure that people meet their basic needs and enjoy decent lives regardless of their nationality, color, sex, religion and social class, etc. This section discusses the mainstream goods-based approaches as the metrics of justice, including the Rawlsian social primary goods approach, the capability approach, and the equal opportunities of welfare approach. All of these approaches "have sought to answer the question "what should we look at, when evaluating whether one state of affairs is more or less just than another'” (Brighouse and Robeyns 2010, p. 1).

\subsection{Goods-Based Approach versus Rights-Based Approach}

Goods-based approaches, alongside the discourse of human rights, add important clarification to the concept of global justice. They are deemed complementary to the discourse of human rights for the following two main reasons.

First, there is a gap between the nominal recognition of rights and the actual satisfaction of needs. In addition to the highly abstract language of human rights, we still need the down-to-earth language of goods to determine the materials and institutional support that the government is obliged to provide (Nussbaum 2011).

Second, the human rights approach - the libertarian or neoliberal understanding of rights - is widely criticized for its excessive emphasis on the "negative" aspect of liberty. (For the distinction between negative and positive liberty see Berlin 1958). Instead of merely "keeping hands off" to ensure the absence of interference, the government needs to do more in order to "positively" secure the basic goods for people to achieve their desired lives (Nussbaum 2004, 2011). 


\subsection{Historical Analysis of the Connection Between Goods and Justice}

Theoretical connections between goods and justice can be traced back to ancient Greek philosophy. Aristotle held that a "just" government must pay attention to common goods, while an "unjust" government pays attention to the goods of the rulers (Aristotle 1984). When common goods conflict with private goods, the latter is always secondary. This perfectionist view, with a comprehensive account of good, is labeled the "unitary conception of common good" by Held (1970). It was further developed in Christian thought, especially in Roman Catholicism, before the advent of liberalism in the Seventeenth century. Since Hobbes offered an interpretation of human nature as desirous of the satisfaction of private needs, private goods have gradually become a legitimate motive and gained moral authority (Douglass 1980). From the point of view of the contractarians, pursuing private interests is considered legitimate since it is supported by natural law as the "natural right" (Hobbes 2016; Locke 1982; Rousseau 1978). This is how the discourse of "rights" enters the debate and replaces "common goods" as the most important element in the interpretation of the conception of justice.

\subsection{Three Approaches to the Goods-Based Conception of Global Justice}

\subsubsection{Primary Goods Approach ${ }^{7}$}

Against this backdrop, Rawls offered a new interpretation of goods as an attempt to fit the rights-justice discourse. On the basis of the liberal commitment that individuals have an interest in being able to make their own choices without violation by the "good of all", Rawls propounded the idea of "primary goods", which are defined as the basic goods that everyone needs for the satisfaction of their various ends, to replace the unitary and comprehensive conception of "common goods". He argued that "primary goods... are things which it is supposed a rational man wants whatever else he wants... with more of these goods men can generally be assured of greater success in carrying out their intentions and in advancing their ends" (Rawls 1971, p. 92). More specifically, although individuals have different ends and various life plans, primary goods are necessary means. In this case, "good" is no longer an encompassing idea that regulates every aspect of citizens' lives, but is the primary material for individuals to fulfil their specific rational desires. ${ }^{8}$

\footnotetext{
7 The goods based approach here focuses on the material and institutional goods that the government is obliged to provide to ensure rights. Thus, it should not be understood as consequentialism (which refers to outcome focused approaches such as utilitarianism), according to which Rawls is certainly not a goods-based theorist. It endorses the basic principles of the rights-based conceptualization of global justice, just as Rawls did in his theory of justice. And "goods" here indicates the unit of distribution. We want to thank Charles Beitz and Kok-Chor Tan for pointing out the differences. More explanation of the relationship between our rights-based and goods-based approaches will be offered later.

8 It should be noted that Rawls distinguishes two theories of the good. One is called the "thin theory" and the other is called the "full theory". The purpose of the thin theory is to "secure the premises about primary goods required to arrive at the principles of justice. Once this theory is worked out and the primary goods accounted for, we are free to use the principles of justice in the further development of what
} 
Rawls's view of primary goods involves rights and basic liberties, income and wealth, powers and prerogatives of office, and the social bases of self-respect. Generally speaking, it includes both materials and relations that we generate together through social interaction. ${ }^{9}$ It is a requirement of justice for the government to maintain the social conditions that answer to the primary goods of individuals (Rawls 1982, 2001).

Defenders of the primary goods approach to justice include Thomas Pogge (2002), Freeman (2006), Richardson (2006), and Norman Daniels (2010), among others. They defended this approach against the capability approach, an alternative metric of justice that we discuss subsequently.

\subsubsection{Capability Approach}

As an improvement on the Rawlsian approach of primary goods, Amartya Sen and Martha Nussbaum developed the capability approach. Sen argued that the primary goods metric fails to notice the inter-individual variations between people, such as metabolism, intelligence, and political and physical environments. These variations, together with primary goods, determine the extent to which people can achieve their purposes and ambitions. Thus, provision merely of primary goods is not enough to meet the requirements of justice (Sen 1980, 1990). In this sense, Sen argued that we should focus on people's being and doing, that is, their capabilities.

Nussbaum developed a well-known list of the ten central human capabilities: life; bodily health; bodily integrity; senses, imagination and thought; emotions; practical reason; affiliation; other species; play; and control over one's environment (Nussbaum 2006). These capabilities require "many things from the world: adequate nutrition, education of faculties, protection of bodily integrity, liberty for speech and religious self-expression, and so forth. If this is so, then we all have entitlements based on justice to a minimum of each of these central goods" (Nussbaum 2004). In this way, Nussbaum justified the capability approach in the framework of global justice.

It should be noted that the capability approach, although emphasizing peoples' being and doing, in no way denies the importance of resources, materials, social institutions, and other forms of goods with regard to people's well-being. Scholars such as Henry Richardson (2006) have shown that the primary goods approach and the capabilities approach can be combined into a coherent framework.

\footnotetext{
Footnote 8 (continued)

I shall call the full theory of the good." The primary good, or the thin theory of the good is common in the sense that it is desired by all individuals for the satisfaction of their specific needs.

9 We want to thank Charles Beitz and Mathias Risse for their comments on the Rawlsian idea of primary goods.
} 


\subsubsection{Equal Opportunities for Welfare}

Alternative approaches exist in addition to the two metrics discussed above. Richard Arneson (1989) offered an account of justice with the idea of "equal opportunities for welfare". He concurred with Sen's criticism of the Rawlsian primary goods approach. But with regard to the capability approach, he also doubted "whether there are any objectively decidable grounds by which the value of a person's capabilities can be judged apart from the person's preferences" (Arneson 1989, pp. 91-92). The valuation of capability independent of preferences, in his view, "presuppose[s] the adequacy of an as yet unspecified perfectionist doctrine" (Arneson 1989, p. 92). As a result, he understood "welfare" as preference satisfaction. Goods must be distributed equally among people to the degree that the distribution ensures the same opportunities for each person to satisfy his preferences. Other variants of this idea can be found in the works of Cohen (2011), Otsuka (2003), and John Roemer (1998).

\subsection{Summary}

Briefly, the three approaches, although presenting disagreements about the details of goods distribution, share the same commitment that the government, as the primary agent of justice, has the responsibility to distribute basic social goods (in a broad sense) to ensure that basic rights are met and satisfied. More specifically, the government should maintain a basic social order to protect citizens' security, provide primary materials for citizens' basic survival, improve the system of education to promote equal opportunities, and provide equal employment opportunities to ensure that individuals with similar capabilities have similar prospects, regardless of their gender, class or background.

Similar ideas exist in Chinese philosophy. Confucianism holds the view that the government should "extensively confer benefits on the people and assist all" (Confucius 2018), and Mozi (2003) argued that good governance is based on universal justice, which requires the government to "enrich the people, increase the population and bring stability and order to the nation". These theories support the goodsbased idea of justice from a non-Western backdrop and reflect its wide applicability in various cultural contexts.

\section{Virtue-Based Conceptualization of Global Justice}

Alongside the two approaches mentioned above (essentially generated in the West), one focusing on rights and the other on public goods, there is another approach to global justice, largely a non-Western one which focuses on virtue, that deserves our attention. Its significance makes it important to include here. Moreover, this approach of justice as virtue, if applied today globally, could help us overcome the one-sidedness that the other two approaches may lead to as they view respect for human rights or provision of public goods simply as a mandatory obligation for 
international society, national governments and individual members. It will be a full testament to the significance of global justice as a noble virtue which the actors concerned are willing to acquire.

To put it another way, in the issue of global justice, the difference between the virtue approach and the other two approaches is that it does not regard people merely as passive practitioners who have to obey certain coercive obligations of global justice, nor as inactive recipients who have urgent needs for certain public goods and must be satisfied. Instead, it first regards people as positive actors who have free will, and in particular a sense of justice, and are willing to make conscious efforts to achieve the global justice of respect for human rights and provision of public goods. In this distinct way, global justice presents itself as a voluntary and noble virtue of human actors, not merely as some mandatory duties for human actions (Liu 2017).

\subsection{The Confucian and Mohist Views of Justice as a Virtue}

In the Eastern tradition, more specifically in China, Confucians proposed "exercising government by means of virtue", on the basis of the idea that "politics means the government out of justice" as early as 2500 years ago. They advocated that the ruler, as the "sage-king," should pursue a path from "self-cultivation, family regulation, country governance to peace restoration in the world" and extend his "filial piety" in family life to his "benevolent government" in order to achieve the "great unity", in the context of which everyone in the world would be unified as one (Chan 1963, pp. 14-83).

Their Mohist contemporaries, in contrast, demanded, based on the philosophy of "honoring the worthy," that the ruler possesses "universal love" as a virtue and "promotes what is beneficial to the world", while observing the "universal justice" of "no harm to fellow humans" (Mozi 2003). As a result, in spite of their opposition to each other on such issues as normative justice and the relationship between collectivism and individualism, these two schools did share something in common. Not only did they view the moral affections of human relationships as the primary motive of achieving justice, but they also emphasized the significant role of the noble virtues of sages and elites in justice.

Under their complex influence, the general view of justice in Chinese traditional philosophy not only affirmed the importance of establishing the bottom line of just obligations and providing public goods, but also highlighted the virtuous role of people, in particular moral elites, who voluntarily engage in just acts by virtue of their sense of justice, i.e., their belief in "bravely defending justice" or "taking justice as supreme," formed in their relationship with others.

\subsection{Justice as a Virtue in Western Tradition}

In the west, the view of justice as a virtue, which originated in ancient Greece, is prone to highly value the leading role of reason. When viewing justice as a major virtue of individuals and society (city-state), Plato and Aristotle based it on rational knowledge or wisdom, and, to varying degrees, were critical of emotional desires 
and feelings (Plato 2004; Aristotle 2009). This idea had some impact on the contemporary rights-based approach to global justice through the theories of Immanuel Kant, John Rawls and other deontologists (Kant 1970; Rawls 1971). David Hume, Adam Smith and other philosophers, in particular from Great Britain, on the other hand, have questioned or even rejected the leading role of reason in their view of justice as a virtue, while focusing more on the effects of moral sentiments like sympathy and benevolence on the formation of justice as a virtue (Hume 1948; Smith 1984). To some extent, their ideas influenced the approach to public goods accepted by consequentialists.

Precisely because of the relatively strong and long-term influence of deontology and consequentialism, however, the Western traditional view of justice as virtue has had little role to play in the context of global justice after it was incorporated into the other two approaches. For example, although Rawls described justice as the "first virtue of social institutions" and also discussed people's sense of justice, he emphasized the two principles of domestic justice mainly as mandatory obligations of human action (Rawls 1971). As is well known, this deontological approach has greatly affected the theoretical efforts of most scholars to extend these two principles of domestic justice to a global scale.

\subsection{Contemporary Western Virtue Ethics}

Contemporary Western virtue ethics, which went through a revival in the mid-20th century, focus especially on the contextual effects of people's moral and psychological mechanisms, such as motive, feeling, character and personality, and on their moral virtues and behaviors. Critical of the universalistic, undifferentiated and compulsory tendency of deontologists and consequentialists regarding justice, it attempts to reinterpret interactions between universal justice and particular interpersonal emotions, such as love, friendship, and loyalty. Therefore, it becomes another approach in parallel with the deontologist and consequentialist approaches in contemporary moral philosophy and shares something in common with the Confucian ethics (Slote 1998; Hursthouse and Pettigrove 2016).

Nevertheless, in order to establish its own independent discourse in a theoretical context dominated by deontology, contemporary Western virtue ethics sometimes shows a tendency to dissociate the universal obligations of justice from such particular virtues as love, friendship, and loyalty. As a result, it relatively neglects the fact that justice itself could also become a noble virtue full of personal motivation and emotional implication, in which people voluntarily engage in just acts in their global interpersonal relationships out of their sense of justice. This tendency is also a theoretical reason for the relative weakness of the virtue-based approach in the context of global justice.

\subsection{Theoretic Tasks for the Virtue Approach}

In consideration of the above views of justice as a virtue with far-reaching impacts, the approach to global justice as a virtue is not only theoretically possible but it also 
possesses unique value and significance relative to the other two approaches. First of all, a "modernized" approach to global justice as virtue would overcome the narrow limitations of past views within this school of thought (in particular where they failed to extend the notion of justice globally). Secondly, it would draw lessons from its longstanding tradition of focusing on the voluntary and noble virtues of human actors, making up for the other two approaches' one-sidedness in comparatively neglecting people's personal motivation, humane emotions, autonomous volition, and in particular their sense of justice, and highlight the positive functions of these subjective psychological factors in promoting people to voluntarily achieve global justice.

Of course, this approach does not at all deny the fundamental significance of respecting human rights and providing public goods for global justice. On the very basis of recognizing this fundamental significance, it tries not only to record the actual contributions from wealthy philanthropists and ordinary volunteers/citizens to global justice and to explore how people form and strengthen their sense of justice through human interaction in real life from an empirical point of view, but also to stress the great importance of various actors (including individuals, organizations, and administrative bodies, for example) to regard global justice as a noble virtue to pursue (as opposed to a compulsory obligation they have to abide by), and to encourage people to internalize the external obligation to respect human rights and provide public goods by cultivating and expanding their own sense of justice from a normative point of view.

In other words, the approach to global justice as a virtue does not simply require people to respect human rights and provide public goods as a heteronomous obligation which amounts to thinking: "I am obliged to abide by this, I am obliged to take global justice seriously". Instead, it encourages people to do what they can to help the needy around the world as an autonomous virtue, which amounts to thinking: "I am willing to do this", I am willing to achieve global justice.

From this perspective, establishing the approach of global justice as a virtue as part of the theoretical portfolio of global justice will offer a new and inspiring perspective in terms of pursuing global justice in the context of issues such as protection of vulnerable groups, bridging the gap between rich and poor, educational equality, and improvement of our ecological environment. In particular, this will allow us to highlight the positive role of the subjective dimension of actors, i.e., self-disciplinary motives, emotions, voluntariness, as well as the impact of leaders as role models, all elements that tend to be overlooked. In addition, this will also help us to enhance our theoretical reflection on global justice from the perspective of moral psychology, which is a significant aspect of any theory of justice.

\section{Comparison of the Three Approaches to Global Justice ${ }^{10}$}

Following the above discussion of each of the three approaches to global justice separately, this section focuses on the relationships between them. Through analysis of the similarities and differences, we try to offer a more explicit and

${ }^{10}$ We want to thank Thomas Hale for suggesting to us to conduct a comparison of the three approaches. 
Table 1 Comparison of three theoretical approaches

\begin{tabular}{llll}
\hline & Focus & Argument & Main unit of analysis \\
\hline Rights-based & Basic principles of justice & Justice as mandatory obligations & State and institutions \\
Goods-based & Achievement of justice & Justice as substantive support & State and institutions \\
Virtue-based & Internalization/motive of justice & Justice as a virtue & Individual \\
\hline
\end{tabular}

comprehensive explanation of the structures and characteristics of our three approaches. Generally speaking, in contrast to the traditional approaches (deontological, consequentialism, or virtue theories) that think about justice in separate and competing ways, the three approaches in our project are interdependent with each other and deal with different aspects of justice (Table 1).

Noticeably, as indicated in the table above, the rights-based approach is focused on the basic principles, guidelines, and sources of legitimacy of justice, and views the requirements of justice as mandatory obligations and legal duties of states and institutions. The goods-based approach emphasizes the achievement of justice by states and institutions, and especially the material and institutional support that the governments or institutions are obliged to provide. The virtue-based approach discusses the internalization or motive of justice, and it sees justice as a virtue that one is willing to acquire rather than a rule one is forced to obey. We agree with Habermas that self-motivation in moral practice in the modern world is very weak and powerless, because we inevitably encounter the dilemma of the "motivational deficit" at the level of voluntary moral action with disenchantment in the world, which means post-traditional morality no longer immediately carries the motivational power that converts moral judgments into moral actions. "A morality thus withdrawn into the cultural system maintains only a virtual relation to action as long as it is not actualized by motivated actors themselves. The latter must be disposed to act according to conscience. A principled morality thus depends on socialization processes that meet it halfway by engendering the corresponding agencies of conscience, namely, the correlative superego formations. Aside from the weak motivating force of good reasons, such a morality becomes effective for action only through the internalization of moral principles in the personality system" (Habermas 1996, pp. 113-114). Therefore, a virtuous person who considers justice as a constitutive element of his/her self-identity or value orientation has sufficient motivational force to shoulder moral or legal duties related to global justice.

Secondly, the units of analysis are different in each approach. For the first two approaches, the main units of analysis are states or institutions. For the virtuebased approach, although the main unit of analysis is the individual, in certain cases, states and organizations can also be regarded as "willing" actors holding the virtue of justice supported by the principle of "cosmopolitan but due-diligent responsibilities" (CDDR), as discussed in the next section.

Let's take anti-poverty as an example to illustrate the above. In this case, the rights-based approach addresses the problem of why individuals are entitled to 
the rights to a basic standard of living, and identifies where the source of legitimacy lies. The goods-based approach determines the substantive support that governments or institutions are obliged to provide to ensure these rights. However, the virtue-based approach explores how individuals (state and institutional leaders or any individual) internalize and integrate the principle of helping others in poverty alleviation into their own ethical identities.

Finally, we would like to offer some further clarification of the relationship between the three approaches. The relationship between the three is interdependent rather than separate: it is better to understand the three approaches as three interdependent parts of a holistic interpretation rather than three separate ways to think about justice. The goods-based and virtue-based approaches, although each has a specific focus, share basic principles and commitments with the rights-based approach, and they further develop the conception of justice based on the endorsement of rights. The three approaches are also complementary rather than competing: the rights-based approach provides the basic structure as the "bones." The goods-based approach thinks about justice in concrete terms to provide "muscles," which ensures that in practice the rights are guaranteed. And the virtue-based approach helps us in overcoming the one-sidedness of the rights-based approach that focuses simply on obligations. It, conversely, emphasizes willingness, personal motivation and internalization, to provide a "heart".

\section{Two Evaluative Principles of Global Justice}

The three theoretical approaches aforementioned lay the foundations for the conceptualization of global justice, on the basis of which it will then be possible to identify, evaluate, and assess the performance of various actors involved in carrying out projects, endeavors, or undertakings seeking to promote justice at the global level. The myriad of both the actors involved and the actions taken can render the process of evaluation difficult.

That said, this difficulty can be attenuated, although not entirely eliminated, by some general principles that can serve as guides for the efforts to evaluate. As such, these principles are formulated not only as a way to bridge the gap between theory and practice but also in order to assist us in the selection of the designated areas for evaluation.

Against this background, we are here proposing two clusters of global-justice matters, to which correspond two evaluative principles, which we call: Common but Differentiated and Respective Capabilities (CBDR-RC) and Cosmopolitan but Due-diligent Responsibilities (CDDR). These two evaluative principles, in their conceptualization, aim to connect the theoretical approaches and to compile the indicators in the succeeding section. They are not only consistent with global justice theories, but also justify the selection of issue areas covered in this working paper. From this perspective, they aim at reconciling national interests and global justice under the umbrella of the abovementioned three approaches to global justice. As principles, they help to connect the three approaches to global justice with the 
evaluative indicators compiled. ${ }^{11}$ In order to evaluate the performance of various actors toward the goal of achieving greater global justice, there is the need for these two principles to serve as guidelines, as illustrated in the following diagram:

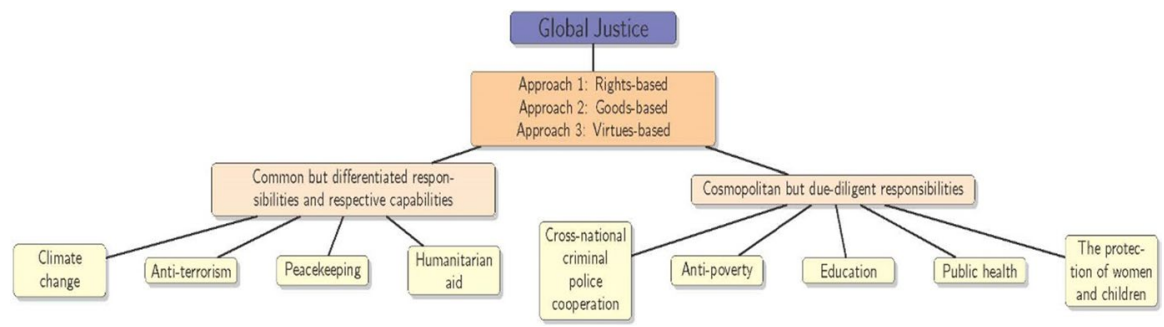

\subsection{CBDR-RC}

The first cluster addresses those issues for which no single actor can be held directly accountable or responsible, matters that can only be tackled through the globally concerted efforts of all stakeholders. These issues involve climate change (global warming), anti-terrorism, peacekeeping, or humanitarian aid. For such matters, the principle of "common but differentiated responsibilities and respective capabilities", first adopted by the United Nations Framework Convention on Climate Change (UNFCCC $)^{12}$ and reaffirmed in the Rio Declaration on Environment and Development, ${ }^{13}$ is arguably a principle that combines moral legitimacy with historical rationality.

\footnotetext{
11 These two principles are, at this stage, essential to our project, as they can help to select, codify and compute those evaluative indicators. We will certainly consider adding more principles should our assessment, at a later stage, be expanded to include a wider range of areas. We want to thank Charles Beitz for reminding us of this possibility.

12 The UNFCCC, opened for signature June 4, 1992, 31 ILM 849 (1992), in its Preamble, declares that all parties to the Convention acknowledge that "the global nature of climate change calls for the widest possible cooperation by all countries and their participation in an effective and appropriate international response, in accordance with their common but differentiated responsibilities and respective capabilities and their social and economic conditions" (emphasis added). Article 3(1) of provides that "[t]he Parties should protect the climate system for the benefit of present and future generations of humankind, on the basis of equity and in accordance with their common but differentiated responsibilities and respective capabilities. Accordingly, the developed country Parties should take the lead in combating climate change and the adverse effects thereof." This principle is reiterated in later paragraphs throughout the Convention (cf. Article 4(1), addressing nation- and region-specific development priorities, and Article 12(5) as regards the differentiated timetable set for different countries).

13 At the United Nations Conference on Environment and Development, held in Rio de Janeiro from 3 to 14 June, 1992, available at http://www.unesco.org/education/pdf/RIO_E.PDF, accessed on November 20, 2018. In Principle 7, it provides that "[i]n view of the different contributions to global environmental degradation, States have common but differentiated responsibilities. The developed countries acknowledge the responsibility that they bear in the international pursuit of sustainable development in view of the pressures their societies place on the global environment and of the technologies and financial resources they command".
} 
By definition, this principle addresses the differential treatment of nation-states in terms of their contribution to the global cause of environmental protection, with an equitable consideration of their respective capabilities, financial resources, and different levels of technological sophistication. Responsibilities to protect the general climate system have been allocated on the basis of national strength and capabilities among the collective bodies of international society. Such differential substantial requirements may include providing a more favorable compliance timetable for some groups of parties, allowing others to exempt themselves from the compliance with either some part or the whole of an international agreement, and differentiating financial and technical contributions in accordance with national overall strength and capabilities, to name just a few. Such a situation of nonuniform obligations is, more often than not, seen in international conventions on environmental protection, where developed countries are in many instances expected to play a greater role than their developing counterparts in reducing the emission of greenhouse gas (GHG), providing technology transfer to the LDCs and making more financial contributions to the common cause of environmental protection.

Although this principle was first proposed as a guideline for determining the respective responsibilities falling on each and every nation-state, it is expansive to the extent that it is capable of serving as a benchmark for other global justice areas such as anti-terrorism or global peacekeeping.

Similar to climate change and globally concerted efforts to preserve the whole ecological system, the call to combat terrorism is not delimited by national boundaries. The global nature of terrorist activities, as seen in the cross-national networks linking terrorists from different locations in a coordinated effort to share information, pool resources, and launch terrorist attacks, demands that we adopt a global approach in our countermeasures. Similarly, the need for peacekeeping in politically and socially unstable areas equally requires that each and every nation contribute, either in money or in personnel, to engage in helping to end conflicts and restore law and order in conflict areas.

The principle of common but differentiated responsibilities and respective capabilities emphasizes that actor- or region-specific contributions to the common cause, be it environmental protection, anti-terrorism or global peacekeeping, be differentiated along a few lines. Among the various factors that may have an impact on the way responsibilities are distributed among various actors, several are readily distinguishable, namely the needs of the actor(s), the responsibility for both past and current harms caused, and the technological and financial resources proprietarily owned by the actor(s) (Stone 2004, pp. 290-292).

First of all, where needs are concerned, arguably, an actor, be it an NGO, a nation-state, or a region, will have its needs conditioned on such a wide variety of factors as its geographical location, the vulnerability of the natural environment, and the endowment of natural resources, to name just a few. In the climate change literature, it has been mentioned that low-lying coastal areas may be particularly susceptible to inundation as a result of global warming and the melting of Antarctic ice (e.g., Article 4(8) in UNFCCC). A country or location within the proximity of terroristinfested regions, in another instance, can also create a greater need for international 
coordination and the provision of security. Peacekeeping forces, along the same line of reasoning, will be dispatched to those areas where they are needed the most.

Secondly, the responsibility of an actor also depends on the degree and amount of harms caused, both in the past and present. This allocation shifts the focus from needs to the wrongs done and thus the costs to be incurred. One common argument in environmental scholarship is to assign heavier contributions to developed countries for the pollution they caused in history. The fact that developed nations are cleaner or less polluting now in terms of their emission of GHG does not justify the wrongs they have done in the past. For this very reason, past conduct will need to be taken into account. The responsibility that each and every state bears shall be rendered proportionate to the pressures their respective societies place on the shared environment, where the emission of GHG by any given country, for instance, recognizes no national boundary and exerts a negative impact on the environment shared by the emitting and non-emitting countries alike. In a similar vein, anti-terrorist and peacekeeping efforts should examine the involvement of different actors in the rise of terrorism or disturbance in a region and have responsibility allocated on the basis of this evaluation.

Thirdly, due to different levels of economic development, there is unavoidably a gap among the various actors in terms of their access to resources, both technological and financial, for their preparation for and engagement in a concerted global undertaking (e.g., Castro 2016; Davidson 2017). Those who are better off will be expected to contribute more. This is the case not only because of the lower marginal costs to them, but diminished utility of the resources thus contributed. Take anti-terrorism as an example. The resources contributed by well-ordered societies may at most have marginal influence on the stability of society back home, and in contrast, may have a significant impact on the targeted region or locality. Similarly, many clean technologies, which may help to reduce pollution or the emission of GHG, are proprietarily owned by big corporations or organizations, many of them located in developed nations. Without an international arrangement morally exhorting these actors to make a greater contribution (e.g., technology transfer or sharing), the actors who are technologically or financially in a weaker position may have to wait for a long period until they reach the same or similar level of resourcefulness. Such a delay will not help the globally concerted effort to reach the targeted objective of reduction in the emission of GHG.

During the application of this principle, there may emerge circumstances under which actors will seek to provide aid or assistance to countries that are either their strategic allies or within geographical proximity. Such a bias and preference is justifiable to the extent that our contribution to the cause of global justice will have to start from somewhere, and it accords with our moral intuition that such a choice of partner actor should be guided by an pre-existing closeness, either physical, mental or strategic, which may be termed as a "Confucian Improvement Scheme". "Confucian Improvement" as a concept was first proposed by Zhao Tingyang (e.g., Zhao 2009), who argues for an upgraded version of the concept of the Pareto Optimum, by stressing a win-win situation of coexistence, where actor A gains profit $(\mathrm{A}+)$ only and if only such a gain contributes to the gain of actor B (i.e., B+). He originally intended this concept to solve the problem of only one or a small minority of 
actors gaining benefit during cooperation in a Pareto Optimum scenario. To borrow this term from Zhao, our use here aims to justify an initial preference or bias which may be unavoidable when one actor makes a contribution to the cause of global justice. For instance, the US initiated a "Marshall Plan" to provide aid to post-war Europe, and by the same token, China now may prioritise its aid to the Belt and Road countries. ${ }^{14}$ Such an initial bias or preference can be justified in accordance with the Confucian emphasis on proximity. Nevertheless, we should also acknowledge the limitations of this Scheme, which may aggravate global inequality from a long-term perspective. Ideally, we should allow such a bias or preference to be offset by taking a more expansive, inclusionary approach to extend aid or assistance to those who have the same or greater need of it.

\subsection{CDDR}

The second cluster is concerned with all actors the world over, with reasonably greater attention to the least advantaged. At the outset, this cluster aims to address the issue of inequality at the global level, a category under which falls issue areas like cross-national criminal police cooperation, anti-poverty, education, public health, and the protection of women, children and minorities, to name just a few. These issue areas will be evaluated on the basis of the principle of "cosmopolitan but due-diligent responsibilities".

As the name suggests, the principle of cosmopolitan but due-diligent responsibilities demands that all actors, nation-states included, are morally obligated to provide cosmopolitan aid to the abovementioned matters, in which context the least advantaged will have a due-diligent responsibility. This principle is built on the notion of "mutual accountability" as proposed in the Paris Declaration on Aid Effectiveness, adopted in 2005 at the Second High-Level Forum on Aid Effectiveness and aiming to promote greater partnership between different parties in aid and development. This notion of "mutual accountability" stresses the idea that apart from the development aid provided by a donor country, within the partner or receiver country, there is a sense of accountability that is owed to its citizens as far as development policies, strategies and performance are concerned. The partner country will need to define its own "measures and standards of performance and accountability...in public financial management, procurement, fiduciary safeguards and environmental assessments, in line with broadly accepted good practices and their quick and widespread application". ${ }^{15}$ This declaration aims to increase the effectiveness with which development aid is used in a partner country, so to maximize the social impact of the aid. It has a clear emphasis on the receiving partner country in exercising due care and accountability in managing the received funds or aid from a donor.

\footnotetext{
14 We want to thank Robert O. Keohane for bringing to our attention those diverging national agendas in different parts of the world.

15 Section I.3 (iii) and (vi), Paris Declaration on Aid Effectiveness (2005), at http://www.oecd.org/dac/ effectiveness/34428351.pdf, accessed on December 5, 2018.
} 
At the global level, adding the Dworkinian proposition of "ambition-sensitive but endowment-insensitive" to the notion of "mutual accountability" is useful. As Dworkin argues, "we must, on pain of violating equality, allow the distribution of resources at any particular moment to be...ambition-sensitive. It must reflect the cost or benefit to others of the choices people ["actors" as in our case] make so that, for example, those who choose to invest rather than consume, or to consume less expensively rather than more, or to work in more rather than less profitable ways must be permitted to retain the gains that flow from these decisions". The idea of "ambition-sensitivity" is "endowment-insensitive" to the extent that it must "not be affected by differences in ability of the sort that produce income differences in a laissez-faire economy among people with the same ambitions" (Dworkin 2002, p. 89).

This can be extended to actors at the global level, suggesting that the distribution of resources at the global level in our efforts to combat inequality should respect the ambition of the actors involved in improving the living conditions for the least advantaged within their respective jurisdictions. Similarly to the principle of subsidiarity (e.g., Garrick 2018; Cahill 2017; van Riel 2009), the CDDR emphasizes the necessity for smaller, less advantaged unit(s) to exercise their initiatives before the intervention of some larger, more resourceful counterpart(s). ${ }^{16}$ Having said that, we should also recognize the fact that the CDDR does not have an in-built assumption of some taken-for-granted hierarchy between and among various actors, regardless of their differences in terms of economy, financial well-being, or social development, which is where the stress on "endowment-insensitivity" steps in. By definition, such distribution should not be conditioned on the natural endowments possessed by an actor, so that this actor, as long as it is ambitious and exercising due care, should be encouraged to thrive on the gains of its ambitions. For instance, at the global level, although all nation-states are morally obligated to provide cosmopolitan aid to the least advantaged, the country, region, or community at a disadvantage should be encouraged to work hard on their own, namely to take due-diligent responsibilities for improving the conditions of their people. Being at a disadvantage does not exclude the need to as much as possible take responsibility for one's life and exercise agency.

As far as the definition of "due diligence" is concerned, it is a term that is borrowed from legal scholarship. As defined in the Merriam-Webster Dictionary, due diligence, as a legal term, refers to "the care that a reasonable person exercises to avoid harm to other persons or their property". Here we borrow this term and give it an expansive reading, extending the actor who exercises such care from a "person" to a wider, larger entity, such as a nation-state, NGO, or big corporation. This term stresses the fact that an entity has to act with care, in a reasonable manner, to avoid causing harm to others' well-being, property or other things associated with them. What matters here is avoiding harm.

\footnotetext{
16 We want to thank Thomas Hale for suggesting to us a possible comparison with the principle of subsidiarity.
} 
To give an example, in business transactions, due diligence may involve a systematic inquiry, either by a stakeholder or a third party, of an organization in order to assess its performance. In contrast with what happens in the world of business, when it comes to the performance of the nation-state there is no established system of auditing, investigation and monitoring, especially from a legal standpoint (with the associated power, qualification and mandate). Different from the obligations of a transactional kind and with a commercial nature, such duties and cares are in many instances anticipated on the part of nation-states absent the interreference from any outsider or third party. Largely moral and political, these matters of due care, to be performed diligently by the nation-state and not less numerous than the former kind of responsibilities, are in general targeting residents dwelling within a given territory, under the specific jurisdiction of one particular nation-state. By this principle, the cost of providing public goods is borne privately by each and every nation-state, whereas the derived benefits of a public, which is as well provided for as free from miserable living conditions or abominable public health threats, are available to the collective bodies of international society at large. ${ }^{17}$

From a general point of view, the principle of "cosmopolitan but due-diligent responsibilities" views the issue of such obligations as falling within national jurisdiction, in the context of which nation-states are expected to provide a series of public goods to their people within their respective territories-both goods for citizens and for foreign nationals (e.g., refugees or international visitors). This principle is a cosmopolitan one to the extent that, in addition to ensuring that people can benefit from law and order, and food and shelter, it encourages the fostering of ties across national boundaries and contributes to the reduction of warfare, poverty, and humanitarian disaster. As for the matters that fall within the general scope of national jurisdictions, and about which nation-states are expected to exercise due care in a diligent manner, it is important for nation-states to be responsible for these tasks, for if these costs are not borne by nation-states, they will have to be borne by some third party or international society in general. But if there is an unwillingness on the part of the third party or international society to bear the costs, there is a chance that the situation will escalate and become a serious problem of injustice, with arguably a negative significant global impact. Indeed, a state that fails to provide food, security, shelter, and stability to its own citizens can easily lead to an outflow of migrants to other countries or regions, resulting in refugee crises, both in the country where the crisis has started and the receiving countries.

\footnotetext{
17 For a discussion of this issue, see Sandler and Arce (2003). In this respect, there is a dis/similarity between the CDDR and the doctrine of the "Responsibility to Protect". These two are similar to the extent that they obligate actors (predominantly nation-states) to provide essential goods to the residents or citizens within their scope of jurisdiction. Nevertheless, the CDDR is more expansive than the latter, in the sense that the latter, as enshrined in international agreements, only prescribes the worst forms of harms to humanity (e.g. genocide, chemical weapons or other crimes against humanity). The CDDR, by way of contrast, aims to bring to our attention those efforts by nation-states that have been long taken for granted, albeit significant in their contribution to the global-justice cause. See e.g. Staunton 2018, and Sirleaf 2018. We want to thank Darrel Moellendorf for bringing this point to our attention.
} 
The principle of cosmopolitan but due-diligent responsibilities generates benefits beyond the nation-state. For example, in ensuring that the population of a country is not exposed to public health threats such as SARS, bird flu, Ebola, or tuberculosis, the duty to act rests primarily with the national government. But, in the process the actions of the national government can also bring benefits at the international level, for a number of public goods at the international level, available to all and enjoyable by all communities across the globe, such as freedom from terrorism, also have their origin in the nation-state (Sandler 2003, 2005). This is to say that the duty of the provision of public goods to residents within a specific national jurisdiction, while seemingly circumscribed, has in fact a cosmopolitan dimension for the benefit of all mankind. The welfare, safety, and rights of a community, and the need for them to be well protected, are a key aspect of building a cosmopolitan international society where harmony and peaceful coexistence prevail. To be sure, it is a complex endeavor to implement a universally accepted conceptualization of what constitutes a decent society. At minimum this presupposes the absence or removal of those public bads or impediments in the way of the pursuit of happiness-however defined by whichever party. And this is rooted in a shared need for subsistence, development, and well-being, a need that is valid across boundaries, be they national, cultural or religious. In the end this is how it may be possible to create a state of "responsibility-sensitive equalitarianism" (Inoue 2016) that will help to reduce inequalities at the global level, where actors are encouraged to be responsible for providing public goods, protecting the rights of community members, and exercising due care to prevent harm to others.

\section{Methodology}

Following the analysis of the three theoretical approaches and the two evaluative principles mentioned above, this section turns to the more practical part of operationalization and measurement. The two clusters of global-justice issue areas mentioned above allow us to focus on measurement, data collection and index formulation around nine issue areas: (1) climate change (global warming), (2) peacekeeping, (3) humanitarian aid, (4) counter-terrorism, (5) cross-national criminal police cooperation, (6) anti-poverty, (7) education, (8) public health, and (9) the protection of women and children.

The first five issue areas fall into a category in which no single actor can be held directly accountable or responsible. They are issue areas that can only be tackled with through the globally concerted efforts of all stakeholders, to which the CBDR-RC principle applies. The last four issue areas can be grouped under a category that is concerned with all actors the world over, with, in reasonable fashion, greater attention given to the least advantaged, to which the CDDR principle applies. On the surface, the last four issue areas are primarily focused on the national level. Some may find it difficult to see the connections between these national public goods and their contribution to global public goods. In fact, on the one hand, the last four issue areas have created problems that significantly contribute to the issue of inequality at the global level, which in turn make this world unjust. On the other hand, the global community, and 
especially the United Nations, has taken many measures (e.g., the Sustainable Development Goals) to solve these problems in less developed countries by virtue of the motivation to build an equal, just and prosperous world (see e.g. Foa and Tanner 2012; IPCC 2013; LeBar and Slote 2016; UNDP 2013, 2018; Wolff et al. 2011).

This methodology section proceeds as follows: first, we introduce the operationalization and measurement methods for each of the nine issues at the global level (see Table 2); second, we discuss potential data sources, which we have already explored, as well as data collection and aggregation methods; finally, we clarify some data limitations as caveats for potential users.

\section{Measurement}

\subsection{Climate Change}

Global warming is a real and disastrous phenomenon, with many destructive effects. Scientists have concluded that it is extremely likely that human influence has been the dominant cause of the observed warming since the mid-twentieth century. If all countries remain passive about this global challenge, the situation is going to worsen, with dramatic consequences globally. On the other hand, if countries come together and engage in concerted efforts to combat global warming, we can significantly alleviate the negative impacts of climate change on this planet.

The United Nations climate change conferences have worked hard to bring together all member states to deal with these unprecedented global challenges. Despite the recent US withdrawal from the Paris Agreement under the Trump Administration, other countries have not ceased their efforts to combat climate change. To measure each country's efforts to deal with global warming is challenging and difficult. Our approach to evaluation and measurement is to focus on the financial contributions made by each country to several major global climate change funds, including the Global Environment Facility, the Special Climate Change Fund, the Least Developed Countries Fund, Adaptation Fund and the Green Climate Fund. In the meantime, we also measure each individual country's transition to a low-carbon society by focusing on the indicators of carbon dioxide $\left(\mathrm{CO}_{2}\right)$ emissions per capita and carbon intensity.

\subsection{Peacekeeping}

World stability continues to be undermined by conflicts. Justice will remain out of reach if wars continue to be a significant feature of the international landscape. That is to say that one of the conditions of global justice is to ensure that all countries contribute to creating and maintaining peace, regionally and globally. Although, arguably, at times one single country (such as a great power) can be powerful enough to play a major role in establishing and maintaining peace in unstable areas or regions, peacekeeping and peacemaking conducted by the joint efforts of nationstates and multinational peacekeeping forces seem to be a wiser course of action. It is in this context that UN peacekeepers, with the participation in multinational joint 


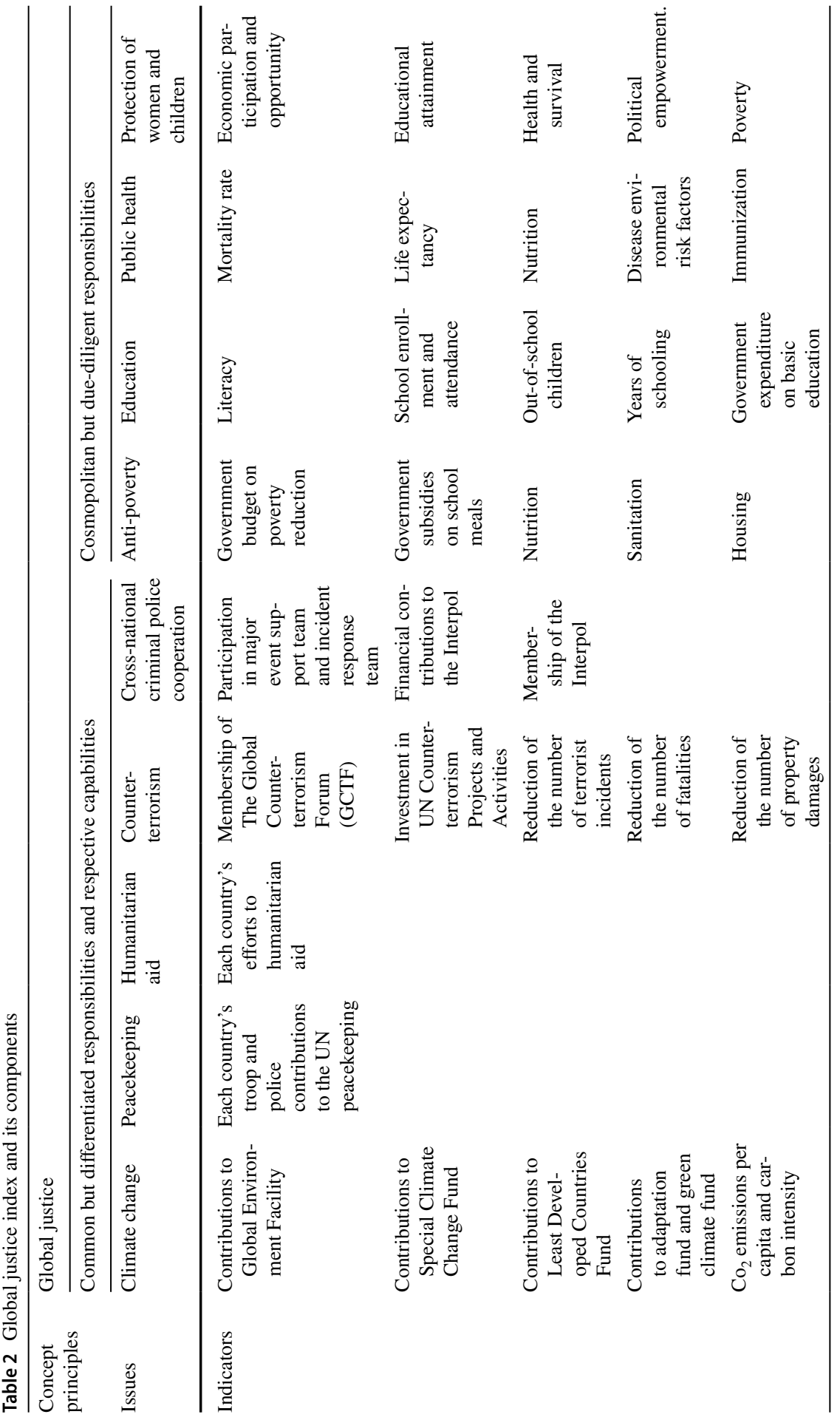




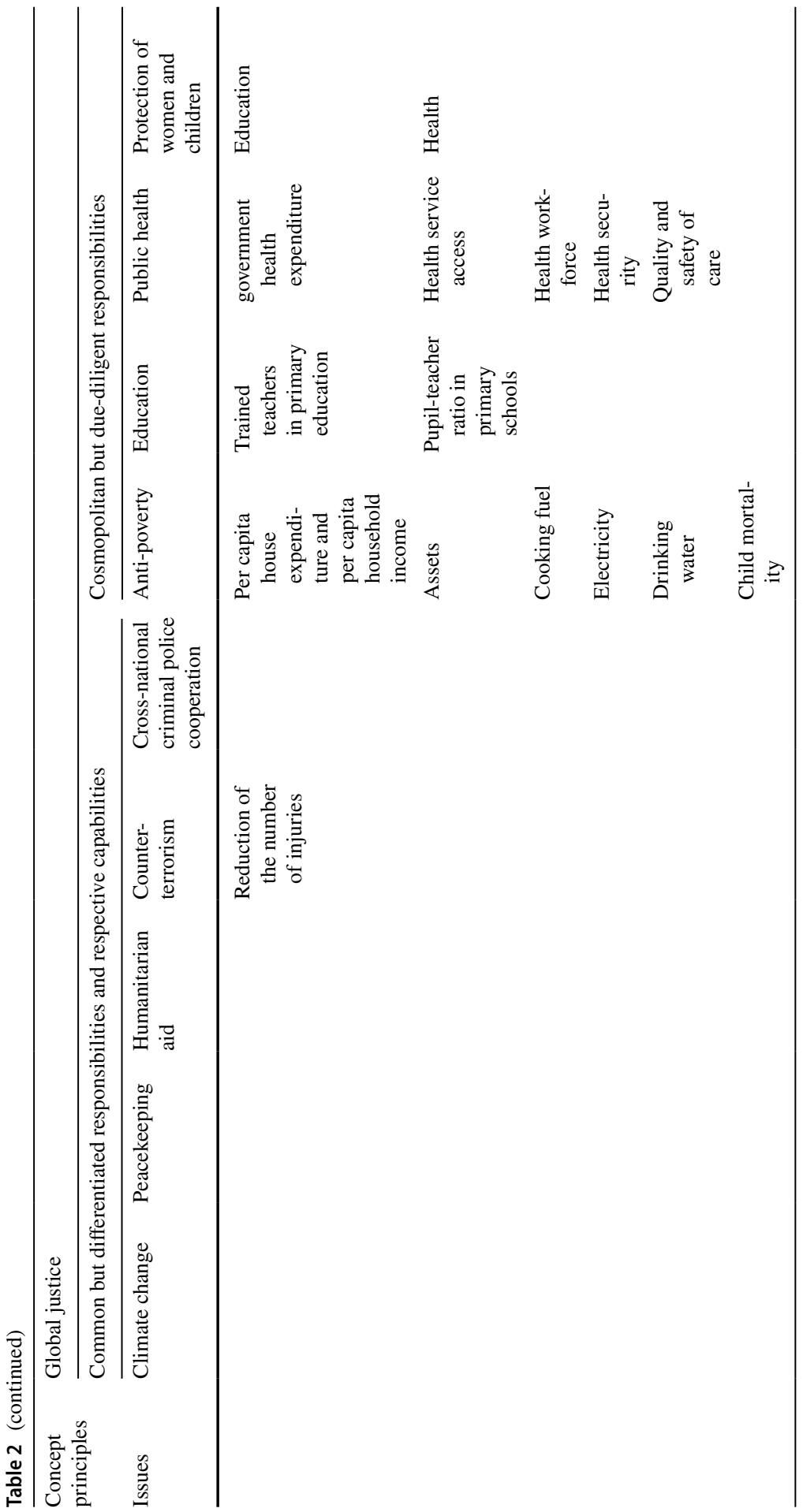


forces, can be deployed to assist war-torn or conflict-ridden countries on their way to peace and reconstruction. Since the 1950 s the track-record shows that UN peacekeeping has made significant contributions to regional and global security.

UN peacekeeping is a truly global effort to maintain international peace and security. All countries, big and small, developed and developing, can participate and make contributions. To measure a country's effort to promote global justice by contributing to UN peacekeeping, we intend to evaluate each country's troop and police contributions to UN peacekeeping. Needless to say, this is not the only way to measure a country's participation in peacekeeping. However, this is arguably one of the most effective and significant ways.

\subsection{Humanitarian Aid}

The gap between rich and poor countries not only exists but has been widening. Narrowing this gap is a key aspect of the global justice agenda. To achieve this goal, developed countries are encouraged to provide their developing counterparts with substantial aid and assistance. A long-standing United Nations target is that developed countries should devote $0.7 \%$ of their gross national income to official development aid (ODA). But humanitarian aid should not be limited to OECD countries' ODA. Other developing countries can also contribute to global humanitarian aid based on their capabilities, as many developing countries are currently doing. Thus, we can measure each country's efforts to humanitarian aid by evaluating their financial contributions to global humanitarian affairs.

\subsection{Counter-Terrorism}

Since the outbreak of the 9/11 attack, terrorism has been viewed as a major challenge to global society and hence to global justice. Counter-terrorism efforts by global partners are a significant aspect of the global justice agenda, if only in the sense that they are meant to combat and reduce terrorist violence and its devastating effects. Given the fact that terrorism is such a contested term in domestic and international politics, we adopt the commonly-used definition of terrorism by the UN Office of Counter-Terrorism. ${ }^{18}$ In order to assess the dimension of counter-terrorism at a global level, we divide this issue area into two aspects, namely performance and contribution.

First, we intend to focus on the performance of counter-terrorism initiatives, which will be measured by the reduction over time in the number of terrorist incidents, casualties, injuries and incidences of property damage (here it should be kept in mind that the number of terrorist incidents is not exclusively linked to the performance of counter-terrorism, it could be linked to the evolution of the context).

\footnotetext{
18 We would like to thank Darrel Moellendorf for suggesting to us an authoritative definition of terrorism at the global level.
} 
Second, we intend to focus on the contribution of each country to global counter-terrorism efforts, which we plan to measure on the basis of membership of the Global Counterterrorism Forum (GCTF), and investment in UN Counter-Terrorism Projects and Activities listed in the United Nations Global Counter-Terrorism Strategy.

\subsection{Cross-National Criminal Police Cooperation}

Transnational crimes can pose serious challenges to global justice as they harm the interests of citizens beyond the jurisdiction of a single nation-state. As an important part of improving global justice, fighting transnational crimes has been a major domain of global cooperation. To assess the dimension of fighting transnational crimes at a global level, we plan to focus on the contribution of countries to fighting transnational crimes. This will be measured by their membership of and financial contributions to Interpol, as well as participation in major event support teams and incident response teams. The related issue areas will include cybercrime, drug trafficking, genocide, human trafficking, money laundering, weapons smuggling, and wildlife and forest crimes.

\subsection{Poverty Alleviation}

As one aspect of the issue of inequality at the global level, poverty has been widely considered a major challenge to global justice for a long period of time. There are many ways in which researchers and policymakers try to measure poverty (Dhongde 2017). Since October 2015, the World Bank has used a poverty line of $\$ 1.90$ a day at 2011 PPP to estimate global poverty. Although the problem of poverty has typically been addressed at the national level, it has strong implications for achieving equality and justice at the global level. ${ }^{19}$ To assess the dimension of poverty from the perspective of global justice, we generally focus on two aspects of poverty alleviation.

First, in the context that enjoying basic living standards is widely viewed as an individual's basic human right, we first focus on the performance in poverty reduction, measuring the extent to which an individual's rights with regard to living conditions are adequately protected and improved. Following a large body of literature and some commonly-shared measurement standards, we use a set of indicators to measure the performance of a particular country in terms of poverty reduction, including nutrition, child mortality, drinking water, electricity, housing, cooking fuel, sanitation, assets, per capita house expenditure and per capita household income (converted through the consumer price index), and so on and so forth.

Second, improving the living conditions for citizens is also considered a government's responsibility, for which we focus on a government's effort to lift people out of poverty, measuring the extent to which a government invests its financial resources in poverty alleviation. Several indicators will be included in this

\footnotetext{
19 We would like to thank Nannerl Keohane and Jean Marc Coicaud for suggesting we highlight the connection between national governance and global justice.
} 
measurement, for instance government budgets for poverty reduction, and government subsidies on school meals, to name just two.

\subsection{Education}

Education is widely considered a fundamental resource for both individuals and societies. Basic education is perceived not only as an individual's right, but also as a government's duty and responsibility. Although education has been widely considered as a national public good, its deficit constitutes an issue of inequality at the global level and its improvement contributes to global justice. ${ }^{20}$ To assess the dimension of education for a country from the perspective of global justice, we generally focus on two aspects of education.

Since basic education is widely considered as an individual's fundamental right, we first focus on the performance of basic education, measuring the extent to which an individual's educational right is adequately protected. Following existing academic literature, we use a set of indicators to measure the performance of basic education (e.g., literacy, school enrollment and attendance, out-of-school children, and years of schooling).

Second, providing basic education to people is also broadly viewed as a government's duty and responsibility. In order to measure this, we focus on the government's effort to improve its basic education nationwide, measuring the extent to which a government invests its financial resources in basic education. The indicators used to measure this may include government expenditure on basic education, trained teachers in primary education, and pupil-teacher ratio in primary schools, to name just a few.

\subsection{Public Health}

Similar to education, the deficit in public health constitutes an issue of inequality at the global level and its improvement contributes to global justice. In measuring public health, we then follow the same method as used in measuring education and divide the dimension of health into two aspects. First, we focus on health-related performance, measuring the protection of an individual's right to health. The indicators adopted will include mortality rate, life expectancy, nutrition, disease environmental risk factors, and immunization.

Second, we focus on a government's effort to improve its health system. The following indicators will be used to measure this aspect: government health expenditure, health service access, health workforce, health security, and quality and safety of care.

\footnotetext{
${ }^{20}$ We would like to thank Nannerl Keohane and Jean Marc Coicaud for suggesting we highlight the connection between national governance and global justice.
} 


\subsection{The Protection of Women and Children}

This issue area involves gender inequality and children's protection. Protection of women and children is also broadly viewed as a government's duty and responsibility, and its achievements largely contribute to global justice. ${ }^{21}$ We firstly measure gender inequality from the perspective of gender gaps in resources and opportunities. The indicators used will be economic participation and opportunity, educational attainment, health and survival, and political empowerment. Second, we plan to measure children's protection from the perspective of poverty alleviation, education, and public health. The indicators used will come from the above three issues, all of which involve children's protection.

\section{Data Availability}

To measure the aforementioned nine issue areas, we need to take into account the suitability and availability of data sources. Ideally, the data to measure global justice must be collected by the same method and follow the same standard. In reality, however, it seems impossible to meet this criterion completely since we have nine different issues to measure and the data on each issue may be created by different actors. As an alternative means, the United Nations and its affiliated agencies, such as The World Bank and The World Health Organization, have collected rich data with regard to the nine issues at the global level. One major merit of these data is that they do not serve particular countries but global common values, and therefore are relatively neutral. ${ }^{22}$ For specific issues, the details of data selection are as follows.

As peacekeeping, climate change and humanitarian aid are priorities of the United Nations, we can find a plethora of information and data on these from the $\mathrm{UN}$ and its related agencies. The peacekeeping data are summarized monthly and collected by the UN. Climate change fund information can be accessed through the $\mathrm{UN}$ as well. Carbon information is available via the World Bank. Humanitarian aid data is available at the Humanitarian Data Exchange, which is run by the data center of the UN Office for the Coordination of Humanitarian Affairs.

Data on counter-terrorism will be collected and recoded from the Global Terrorism Index (Institute for Economics and Peace), Global Terrorism Database (University of Maryland), UN Office of Counter-Terrorism (The United Nations Global Counter-Terrorism Strategy), and the Global Counterterrorism Forum (GCTF).

The data on fighting transnational crime mainly comes from Interpol and the United Nations Criminal Justice and Crime Prevention Branch. These two informative data sources provide us with raw data that allow us to construct a set of indicators about the contribution of a particular country to fighting transnational crimes.

\footnotetext{
${ }^{21}$ We would like to thank Nannerl Keohane and Jean Marc Coicaud for suggesting we highlight the connection between national governance and global justice.

${ }^{22}$ We would like to thank Darrel Moellendorf for suggesting we discuss the criteria of data collection.
} 
The United Nations and the World Bank have worked on measuring global poverty since the adoption of the Millennium Development Goals (MDG), stated in the UN's Millennium Declaration. The United Nations Development Programme (UNDP) and World Bank Global Poverty Monitoring provide rich and detailed data on global poverty, which allow us to assess not only performance, but also a government's efforts toward poverty alleviation nationwide.

The World Bank and the United Nations Development Programme (UNDP) offer rich information on basic education, which allows to assess not only the performance but also a government's efforts toward basic education nationwide.

The data on health at a country level will come from both the World Health Organization (WHO) and UNDP. In particular, the WHO has built a large and informative dataset on health with a long span of almost three decades at the country level.

The data on women and children also come from the World Bank, WHO and UNDP. The three informative data sources allow us to not only construct a set of indicators about gender gaps, but offer also many direct indicators to measure gender inequality at the country level.

\section{Data Limitations}

A large dataset will be collected, recoded, and aggregated to measure global justice. Ideally the data would measure a government's effort and its achievements not only at the country level but also at the global level. However, it is very difficult, if not impossible, to measure each country's effort and performance all at global level. For example, we have a set of informative indicators to measure each country's effort and its achievements to provide basic education for its own citizens but not for those in other countries. But, as stated in the sections dealing with conceptualization and operational principles, domestic efforts that have global implications will be considered as contributions to human society and thus to global justice.

The second limitation is missing values. The data used in this study mainly come from the United Nations and its related agencies. Although these organizations endeavor to construct high-quality datasets, the problem of missing values, which undermines the comparability of indicators both over time and across countries, is probably unavoidable. For instance, humanitarian aid and peacekeeping data are publicly available, while this is not the case with the climate change fund data. We cannot resolve the problem of missing values if we just rely on the data from United Nations and its affiliated agencies. ${ }^{23}$ To remedy this defect, we will also collect these data from other sources, such as international NGOs, research institutes, and yearbooks if necessary.

No data are ideal. International comparisons of global justice based on aggregated indices from different issue areas entail both conceptual and practical challenges.

${ }^{23}$ We would like to thank for Nannerl O. Keohane's comment. 
Acknowledgements We thank the following scholars for their valuable comments and suggestions on the earlier draft of this paper: Robert Keohane, Nannerl Keohane, Charles R. Beitz, Mathias Risse, Kok-Chor Tan, Yannick Glemarec, Darrel Moellendorf, Ariel Colonomos, and Thomas Hale.

Open Access This article is licensed under a Creative Commons Attribution 4.0 International License, which permits use, sharing, adaptation, distribution and reproduction in any medium or format, as long as you give appropriate credit to the original author(s) and the source, provide a link to the Creative Commons licence, and indicate if changes were made. The images or other third party material in this article are included in the article's Creative Commons licence, unless indicated otherwise in a credit line to the material. If material is not included in the article's Creative Commons licence and your intended use is not permitted by statutory regulation or exceeds the permitted use, you will need to obtain permission directly from the copyright holder. To view a copy of this licence, visit http://creativecommons.org/licen ses/by/4.0/.

\section{References}

Alston, P. 1987. A Third Generation of Solidarity Rights: Progressive Development or Obfuscation of International Human Rights Law? Netherlands International Law Review 29: 307-365.

Aristotle. 1984. Politics, vol. 2. Princeton: Princeton University Press.

Aristotle. 2009. The Nicomachean Ethics (trans: David Ross). Oxford: Oxford University Press.

Arneson, R. 1989. Equality and Equal Opportunity for Welfare. Philosophical Studies: An International Journal for Philosophy in the Analytic Tradition 56(1): 77-93.

Beitz, C.R. 1975. Justice and International Relations. Philosophy \& Public Affairs 4(4): 360-389.

Berlin, I. 1958. Two Concepts of Liberty: An Inaugural Lecture Delivered Before the University of Oxford on 31 October 1958. Oxford: Clarendon Press.

Brighouse, H. and I. Robeyns (eds.). 2010. Measuring Justice: Primary Goods and Capabilities. Cambridge: Cambridge University Press.

Cahill, M. 2017. Theorizing subsidiarity: Towards an ontology-sensitive approach. Icon-International Journal of Constitutional Law 15 (1): 201-224.

Castro, P. 2016. Common but Differentiated Responsibilities Beyond the Nation State: How Is Differential Treatment Addressed in Transnational Climate Governance Initiatives? Transnational Environmental Law 5(2): 379-400.

Chan, W.-T. 1963. A Source Book in Chinese Philosophy. Princeton: Princeton University Press.

Cohen, G.A. 2011. On the Currency of Egalitarian Justice, and Other Essays in Political Philosophy. Princeton: Princeton University Press.

Confucius. 2018. The Analects of Confucius. Ann Arbor: Charles River Editors.

Daniels, N. 2010. Capabilities, Opportunity and Health. In Measuring Justice: Primary Goods and Capabilities, ed. H. Brighouse and I. Robeyns, 131-149. Cambridge: Cambridge University Press.

Davidson, M.D. 2017. Equity and the Conservation of Global Ecosystem Services. Sustainability 9(3): 339.

Dhongde, S. 2017. Measuring Global Poverty. Retrieved December 10, 2018, from http://oxfordre. com/internationalstudies/view/10.1093/acrefore/9780190846626.001.0001/acrefore-9780190846 626-e-259.

Douglass, B. 1980. The Common Good and the Public Interest. Political Theory 8(1): 103-117.

Dworkin, R. 2002. Sovereign Virtue: The Theory and Practice of Equality. Cambridge: Harvard University Press.

Foa, R., and J. C. Tanner. 2012. Methodology of the Indices of Social Development. ISD Working Paper Series 2012-04. Retrieved December 10, 2018, from http://www.indsocdev.org/resources/Metho dology\%20of\%20the\%20Social\%20Development\%20Indices_\%20jan11.pdf.

Freeman, S. 2006. Book Review-Frontiers of Justice: The Capabilities Approach Versus Contractarianism. Texas Law Review 85(2): 385-430.

Garrick, D.E. 2018. Decentralisation and drought adaptation: Applying the subsidiarity principle in transboundary river basins. International Journal of the Commons 12(1): 301-331.

Habermas, Jürgen. 1996. Between Facts and Norms: Contributions to a Discourse Theory of Law and Democracy (trans: Williiam Rehg). Cambridge: MIT Press. 
Held, V. 1970. The Public Interest and Individual Interests. New York: Basic Books.

Hobbes, T. 2016. Thomas Hobbes: Leviathan (Longman Library of Primary Sources in Philosophy). London: Routledge.

Hume, D. 1948. A Treatise of Human Nature. In Hume's Moral and Political Philosophy, ed. H.D. Aiken. New York: Hafner.

Hursthouse, R., and G. Pettigrove. 2016. Virtue Ethics. Retrieved December 1, 2018, from https://plato .stanford.edu/entries/ethics-virtue/.

Inoue, A. 2016. Inequalities, Responsibility And Rational Capacities: A Defence of Responsibility-Sensitive Egalitarianism. Australian Journal of Political Science 51(1): 86-101.

IPCC. 2013. Climate Change 2013: The Physical Science Basis-Summary for Policymakers (AR5 WG1). Retrieved December 10, 2018, from https://www.ipcc.ch/pdf/assessment-report/ar5/wg1/ WGIAR5_SPM_brochure_en.pdf.

Kant, I. 1970. Political Writings (trans: H. B. Nisbet). Cambridge: Cambridge University Press.

LeBar, M., and M. Slote. 2016. Justice as a Virtue. Retrieved November 25, 2018, from https://plato.stanf ord.edu/entries/justice-virtue/.

Liu, Q. 2017. Justice as the Virtue of "No Unacceptable Harm to the Human". Fudan Journal of the Humanities and Social Sciences 10(2): 179-192.

Locke, J. 1982. Second Treatise of Government: An Essay Concerning the True Original, Extent and End of Civil Government. London: Wiley-Blackwell.

Mozi. 2003. Mozi: Basic Writings (trans: Watson, Burton). New York: Columbia University Press.

Nussbaum, M. 2004. Beyond the Social Contract: Capabilities and Global Justice. Oxford Development Studies 32(1): 3-18.

Nussbaum, M. 2006. Frontiers of Justice: Disability, Nationality, Species Membership. Cambridge: Harvard University Press.

Nussbaum, M. 2011. Capabilities, Entitlements, Rights: Supplementation and Critique. Journal of Human Development and Capabilities 12(1): 23-37.

Otsuka, M. 2003. Libertarianism Without Inequality. Oxford: Oxford University Press.

Plato. 2004. Republic (trans: Reeve, C. D. C.). Indianapolis: Hackett.

Pogge, T. 2002. Can the Capability Approach Be Justified? Philosophical Topics 30(2): 167-228.

Rawls, J. 1971. A Theory of Justice. Cambridge: Harvard University Press.

Rawls, J. 1982. Social Unity and Primary Goods. In Utilitarianism and Beyond, ed. A. Sen and B. Williams, 159-185. Cambridge: Cambridge University Press.

Rawls, J. 1999. The Law of Peoples. Cambridge: Harvard University Press.

Rawls, J. 2001. Justice as Fairness: A Restatement. Cambridge: Harvard University Press.

Richardson, H.S. 2006. Rawlsian Social-Contract Theory and the Severely Disabled. The Journal of Ethics 10(4): 419-462.

Roemer, J. 1998. Equality of Opportunity. Cambridge: Harvard University Press.

Rousseau, J.-J. 1978. On the Social Contract, With Geneva Manuscript and Political Economy. New York: St. Martin's Press.

Sandler, T. 2003. Collective Action and Transnational Terrorism. World Economy 26(6): 779-802.

Sandler, T. 2005. Collective Versus Unilateral Responses to Terrorism. Public Choice 124(1): 75-93.

Sandler, T., and D.G. Arce. 2003. Pure Public Goods Versus Commons: Benefit-Cost Duality. Land Economics 79(3): 355-368.

Sen, A. 1980. Equality of What? In The Tanner Lectures on Human Values, 1. 1st ed, ed. S. McMurrin, 196-220. Salt Lake City: University of Utah Press.

Sen, A. 1990. Justice: Means Versus Freedoms. Philosophy \& Public Affairs 19(2): 111-121.

Sen, A. 2009. The Idea of Justice. Westminster: Penguin Books.

Slote, M. 1998. The Justice of Caring. Social Philosophy and Policy 15(1): 171-195.

Smith, A. 1984. The Theory of Moral Sentiments. Indianapolis: Liberty Fund.

Stone, C.D. 2004. Common but Differentiated Responsibilities in International Law. American Journal of International Law 98(2): 276-301.

Tan, K.-C. 2017. What is This Thing Called Global Justice?. London: Routledge.

UNDP. 2013. Human Development Report. Retrieved September 14, 2018, from http://hdr.undp.org/sites/ default/files/reports/14/hdr2013_en_complete.pdf.

UNDP. 2018. Human Development Indices and Indicators-2018 Statistical Update. Retrieved September 14, 2018, from http://www.cl.undp.org/content/dam/chile/docs/desarrollohumano/undp_cl_idh_ Informe-IDH-mundial-2018-Chile.pdf. 
Wolff, H., H. Chong, and M. Auffhammer. 2011. Classification, Detection and Consequences of Data Error: Evidence from the Human Development Index. Economic Journal 121: 843-870.

Universal Declaration of Human Rights. from http://www.un.org/en/universal-declaration-human-rights/ index.html.

van Riel, B. 2009. Subsidiarity and economic reform in Europe. Economist-Netherlands 157 (2): 265-266.

Zhao, Tingyang. 2009. Ontology of coexistence: Relations and hearts (gongzai cunzailun: renji yu renxin). CASS Journal of Philosophy (zhexue yanjiu) 2009(8).

Sujian Guo (Ph.D. in Political Science), an honorary visiting professor and acting dean of the Fudan Institute for Advanced Study in Social Sciences; Professor of Political Science and Director of the Center for US-China Policy Studies at San Francisco State University; former president of Association of Chinese Political Studies; Editor-in-Chief of the Journal of Chinese Political Science, the Journal of Chinese Governance, the Fudan Journal of the Humanities and Social Sciences, and the Chinese Political Science Review; Editor-in-Chief of Rowman \& Littlefield-Lexington's book series "Challenges Facing Chinese Political Development," and Editor-in-Chief of Shanghai People's Press book series of "China in Transition." His research areas include comparative politics and Chinese politics, comparative political economy, Sino-US relations, sustainable energy and environment, democratic transition, and economic transition. He has published more than 60 academic articles, and authored and edited 30 books, including Governance in Transitional China; China's Green Low Carbon Transition; The Political Economy of China's Great Transformation; Global Sustainable Energy Competitiveness Report; Democratic Transitions: Modes and Outcomes; Chinese Politics and Government: Power, Ideology and Organization; The Political Economy of Asian Transition from Communism; Post-Mao China, among others.

Xi Lin (Ph.D. in Political Science), is an associate professor and assistant Dean of the Fudan Institute of Advanced Study in Social Sciences (IAS-Fudan). He received his doctoral degree from the London School of Economics. He was a former member of Higher Education Academy (UK). His main research areas include theories of justice, and the tradition of equity and justice in imperial China. He is the author of Emotions and Politics in Human Society (2012), Rethinking Chinese Jurisprudence and Exploring Its Future (2014), and a dozen of research papers.

Jean-Marc Coicaud is Distinguished Research Professor at the Fudan Institute for Advanced Study in Social Sciences (Shanghai) and Professor of Law and Global Affairs at Rutgers School of Law, Rutgers University, State University of New Jersey, USA. He is an elected member of Academia Europaea.

Su Gu (Ph.D. in Philosophy) is a professor and research fellow at the Fudan Institute for Advanced Study in Social Sciences (IAS-Fudan). His main areas of research are political philosophy and philosophy of law. He is a standing member in the Council of Chinese Association for Modern Foreign Philosophy, member in the Council of Chinese Association for History of Foreign Philosophy, research fellow of Hong Fan Institute of Law and Economics. He has published about 10 academic books including Essential Ideas of Liberalism, A History of Western Political and Legal Thoughts, After Republic: Writings in Political and Legal Philosophy, and over 10 books translated from English including John Rawls: his Life and Theory of Justice. He has been selected by British website The Culture Trip as one of the "Ten Contemporary Philosophers to Read Today" together with Slavoj Žižek, Thomas Nagel, Martha Nussbaum and other leading philosophers in 2017.

Yanfeng Gu (Ph.D. in Social Sciences) is a lecturer and research fellow at the Fudan Institute for Advanced Study in Social Sciences (IAS-Fudan). He received his Ph.D. in Social Sciences at the Hong Kong University of Science and Technology. His primary fields are development economics, economic history, political economy, public administration and social policy. His research interests include market integration, culture, social trust and migration. His work has appeared in Chinese Sociological Review, Journal of Chinese Political Science, Sociological Study (in Chinese) and other leading journals in area studies. 
Qingping Liu (Ph.D. in Philosophy) is a professor and research fellow at the Fudan Institute for Advanced Study in Social Sciences (IAS-Fudan). His areas of specialization include comparative studies of Chinese and Western cultures, moral philosophy and political philosophy, and aesthetics. His representative publications include Loyalty and Filial Piety vs. Humaneness and Justice: A Criticism of Confucian Ethics (2012, in Chinese), The Emotional, the Rational, the Utilitarian, and the Desirable: A Reflection on Popular Aesthetic Culture (1998, in Chinese), and more than 200 academic articles in Chinese and English (over 10 articles published in AHCI journals). From 2014 to 2017, he was consecutively in the list of "Most-Cited Researchers in China" released by the publishing group Elsevier, which means that the total number of citations of his English papers is at the top level among all researchers in the areas of art and humanities in mainland China.

Xuan Qin (Ph.D. in Political Science) is a lecturer and research fellow at the Fudan Institute for Advanced Study in Social Sciences (IAS-Fudan). She received her Ph.D. from the Nanyang Technological University (NTU Singapore). She is also a research assistant in the program of Participedia, which is developed by Archon Fung (Kennedy School of Government, Harvard University) and Mark E. Warren (Department of Political Science, University of British Columbia). Her current research interests fall within the fields of democratic theory, statistical analysis, and data visualization. She has published several articles in SSCI and CSSCI journals.

Guodong Sun (Doctor of Juridical Science) is an associate professor and associate Dean of the Fudan Institute for Advanced Study in Social Sciences (IAS-Fudan). His research fields are legal philosophy and socio-political theory. He is also interested in legal sociology, legal culture, thoughts and cultures in modern and contemporary China. In addition to publishing more than 100 research papers, he is also the single author of Between Legality and Legitimacy: Research on Habermas's Discourse Theory of Legitimation, and published another six (co-authored, edited and translated) books, such as Culture Improving State's Quality: The Mission of Development in Contemporary China, Law as Communication, among others.

Zhongyuan Wang (Ph.D. in Political Science and China Studies) is a lecturer and research fellow at the Fudan Institute for Advanced Study in Social Sciences (IAS-Fudan). He received his doctoral degree from Leiden University (the Netherlands) and had ever worked as a lecturer in the Program of International Studies at Leiden University. His research interests include comparative political institutions, election studies, political representation, local politics and governance, European politics, and governmental big data. His work has appeared in European Political Science, China Information, and the Journal of Contemporary China. He currently serves as an editor for the Journal of Chinese Political Science.

Chunman Zhang (Ph.D. in Political Science) is a senior lecturer and research fellow at the Fudan Institute for Advanced Study in Social Sciences (IAS-Fudan). He received his doctoral degree from the Johns Hopkins University. His research interests are comparative politics, party politics, environmental governance, and international relations. His work has appeared in leading SSCI journals Environmental Politics, Land Use Policy, Journal of Chinese Political Science and top CSSCI journals. He serves as an editor for Journal of Chinese Political Science. 